\title{
INITIAL STUDY OF IMMERSION THERMAL MANIKIN DEVELOPMENT AND ITS MANUFACTURE FROM SOLID BLOCKS
}

\author{
Ivo Pahole, Bogdan Valentan, Daniela Zavec Pavlinić, Mirko Ficko, Jože Balič
}

Preliminary notes

Article presents the development and manufacture of a new generation of thermal manikins that can be used for testing different personal protective equipment as used under extreme environmental conditions. The demonstrated steps from the initial idea towards the final product were taken with the help of modern $\mathrm{CAD} / \mathrm{CAM}$ tools and $\mathrm{CNC}$ manufacturing procedures. This article also presents some of the problems that occurred and had to be solved during the designing, manufacturing and assembly of the thermal manikin.

Keywords: extreme environment; personal protective equipment; safety; thermal manikin

Početna analiza razvoja termalne lutke za uporabu u vodi i njezina proizvodnja iz punih blokova

Prethodno priopćenje U radu se opisuje razvoj i proizvodnja nove generacije termalnih modela (lutaka) koji se mogu koristiti za ispitivanje različite osobne zaštitne opreme kada se rabi u ekstremnim uvjetima. Sve od početne ideje do konačnog proizvoda provedeno je uz pomoć suvremenih CAD/CAM alata i CNC proizvodnih postupaka. U radu se iznose i neki problemi koji su se pojavili tijekom konstruiranja, izrade i sastavljanja termalne lutke, a trebalo ih je riješiti.

Ključne riječi: ekstremni uvjeti okoline; osobna zaštitna oprema; sigurnost; termalna lutka

\section{Introduction}

Thermal manikins, as anatomical shapes of the human body, were first used in the early 1940's [1] when a simple one segment copper-made manikin was introduced by the American army. The need for the development and manufacture came from testing firearms and protective equipment during World War II. From that year onwards, a lot has been changed and more and more sophisticated manikins have been developed with every new model, such as [2] to [4]. There are more than 100 thermal manikins in use worldwide. Tab. 1 lists the milestones in their developments. Each new example represents a significant improvement in technique and approach.

Manikins have started to acquire more individually controlled segments and, with the development of digital technology, new possibilities have been introduced (better heat regulation, better signal quality and control, etc.). Today, well over 100 manikins exist and they are mainly used to obtain tangible results that can be compared with the results of human testing or can be tested within an environment that is extremely unfriendly such as extreme cold and heat (firefighter and military combat clothing, diving suits, CBRN protection, etc.) $[5 \div 8]$.

Thermal manikins of today represent the anatomical shape of the human body and in this way represent a measuring tool, which enables:

- Relevant simulation of human body heat exchange: whole body and regional.

- Measurement of the 3-dimensional heat exchange.

- Integration of dry heat losses in a realistic manner.

- An objective method for measuring segmental heat flux whilst testing different personal protection equipment: military combat clothing including CBRN protection $[21,26]$, fire-fighters' protective clothing, diving suits, pilots' uniforms, etc.
- Provision of values for prediction models: clothing thermal insulation, evaporative resistance and heat loss; overall and regional for the above-mentioned protective ensembles.

- Quick, accurate and repeatable measurements where human testing would be too risky for their lives.

- A cost-effective instrument for comparative measurements and industrial product development.

Table 1 Milestones in the developments of thermal manikins

\begin{tabular}{|c|c|c|c|c|c|}
\hline 1 & One-segment & Copper & Analogue & - & US 1945 \\
\hline 2 & Multi-segment & Aluminium & Analogue & - & UK 1964 \\
\hline 3 & $\begin{array}{c}\text { Radiation } \\
\text { manikin }\end{array}$ & Aluminium & Analogue & - & France 1972 \\
\hline 4 & Multi-segment & Plastics & Analogue & Movable & Denmark 1973 \\
\hline 5 & Multi-segment & Plastics & Analogue & Movable & Germany 1978 \\
\hline 6 & Multi-segment & Plastics & Digital & Movable & Sweden 1980 \\
\hline 7 & Multi-segment & Plastics & Digital & Movable & Sweden 1984 \\
\hline 8 & Fire manikin & Aluminium & Digital & - & US 1945 \\
\hline 9 & $\begin{array}{c}\text { Immersion } \\
\text { manikin }\end{array}$ & Aluminium & Digital & Movable & Canada 1988 \\
\hline $\begin{array}{l}1 \\
0\end{array}$ & $\begin{array}{l}\text { Sweating } \\
\text { manikin }\end{array}$ & $\begin{array}{l}\text { Aluminium } \\
\text { Plastic } \\
\text { Aluminium }\end{array}$ & Digital & $\begin{array}{c}- \\
\text { Movable } \\
\text { Movable }\end{array}$ & $\begin{array}{c}\text { Japan } 1988 \\
\text { Finland } 1988 \\
\text { USA } 1996\end{array}$ \\
\hline $\begin{array}{l}1 \\
1\end{array}$ & $\begin{array}{l}\text { Female } \\
\text { manikin }\end{array}$ & $\begin{array}{c}\text { Plastic } \\
\text { Single wire }\end{array}$ & $\begin{array}{c}\text { Digital, } \\
\text { comfort } \\
\text { regulation } \\
\text { mode }\end{array}$ & Movable & Denmark 1989 \\
\hline $\begin{array}{l}1 \\
2\end{array}$ & $\begin{array}{l}\text { Breathing } \\
\text { thermal } \\
\text { manikin }\end{array}$ & $\begin{array}{c}\text { Plastic } \\
\text { Single wire }\end{array}$ & $\begin{array}{l}\text { Digital, } \\
\text { comfort } \\
\text { regulation } \\
\text { mode }\end{array}$ & $\begin{array}{l}\text { Movable, } \\
\text { breathing } \\
\text { simulation }\end{array}$ & Denmark 1996 \\
\hline $\begin{array}{l}1 \\
3\end{array}$ & $\begin{array}{l}\text { Sweating } \\
\text { manikin }\end{array}$ & $\begin{array}{c}\text { Plastic } \\
\text { Single wire }\end{array}$ & $\begin{array}{c}\text { Digital, } 30 \text { dry } \\
\text { and } \\
125 \text { sweat } \\
\text { zones }\end{array}$ & $\begin{array}{c}\text { Realistic } \\
\text { movements }\end{array}$ & Switzerland 2001 \\
\hline $\begin{array}{l}1 \\
4\end{array}$ & $\begin{array}{c}\text { Self-contained, } \\
\text { sweating field } \\
\text { manikin }\end{array}$ & Metal & $\begin{array}{l}\text { Digital, } 126 \\
\text { zones }\end{array}$ & Articulated & USA 2003 \\
\hline $\begin{array}{l}1 \\
5\end{array}$ & $\begin{array}{l}\text { Virtual, } \\
\text { computer } \\
\text { manikin }\end{array}$ & $\begin{array}{c}\text { Numerical, } \\
\text { geometric } \\
\text { model }\end{array}$ & $\begin{array}{c}\text { Heat and } \\
\text { mass } \\
\text { transfer } \\
\text { simulations }\end{array}$ & Articulated & $\begin{array}{c}\text { China } 2000 \\
\text { UK } 2001 \\
\text { Sweden } 2001 \\
\text { Japan } 2002 \\
\end{array}$ \\
\hline $\begin{array}{l}1 \\
6\end{array}$ & $\begin{array}{l}\text { One-segment, } \\
\text { sweating } \\
\text { manikin }\end{array}$ & $\begin{array}{l}\text { Breathable } \\
\text { fabric }\end{array}$ & $\begin{array}{l}\text { Digital, water } \\
\text { heated }\end{array}$ & Movable & China 2001 \\
\hline $\begin{array}{l}1 \\
7 \\
\end{array}$ & $\begin{array}{c}\text { One-segment } \\
\text { manikin }\end{array}$ & $\begin{array}{l}\text { Windproof } \\
\text { fabric }\end{array}$ & $\begin{array}{c}\text { Digital, air } \\
\text { heated }\end{array}$ & Movable & USA 2003 \\
\hline
\end{tabular}


The challenge of the presented study was to develop a thermal manikin, which would be useful for testing in the water. The main arena of such testing is for diving and pilots' suits, especially for military usages. Such protective suits must provide the user with adequate thermal insulation and to protect him/her from hypothermia.

In order to address the main requirements the manikin should be waterproof and able to be immersed to a depth of at least $3 \mathrm{~m}$ in salted water. The presented variation of the immersion manikin is mainly for clothing testing but with modifications this manikin during future research could also be used for tests of human interactions with the environment.

The main advantages of the presented manikin are:

- immersion and waterproofing,

- robustness, so that the manikin can be used within harsh environments,

- the lightweight of the manikin and the external modules enable fast transport and measurement preparation,

- modularity - several components can be replaced for using the manikin under more extreme conditions or to improve the accuracies of measurements,

- simplicity and modularity enable fast and unproblematic replacements of problematic or damaged segments,

- design that can easily be changed to adapt the manikin to anthropometric data (segment sizes) from other countries,

- $\quad$ fast production due to the uses of advanced and wellknown industrial procedures,

- sound price-to-performance ratio, as well as good price and availability for industrial uses.

\section{Method}

\subsection{Theory}

If a human is accidentally dropped into cold water the principle aim of his protective clothing ensemble is to provide sufficient thermal protection and consecutively prevent a drop in core temperature $\left(T_{\mathrm{c}}\right)$ greater than $2{ }^{\circ} \mathrm{C}$. Such protective ensembles are called immersion suits. Helicopter and plane pilots, rescue services including coastguards, merchant ships, and workers on fishing vessels or gas and oil rigs are all legally bound to carry immersion suits. Immersion suits are made of breathable and fire resistant materials and must provide strength, durability and reliability. Usually the immersion suits' configurations include constant wear coveralls, emergency quick donning suits and reinforced coveralls for high abrasion resistance. However, these suits are used to protect oil industry personnel, who fly over the North Sea and must protect the user under a variety of aviation and marine environmental conditions. Fig. 1 shows a pilot donned in an immersion suit whist lying in cold water.

As the testing of immersion suits within real environmental conditions is infeasible, we have developed a measuring tool, the so-called immersion thermal manikin. The boundary conditions for its manufacture were compatibilities with waterproofing, immersion and heating with electric heaters. The decision was made to produce a robust and consequently reliable manikin that would be capable of measuring the thermal insulation whilst immersed in cold and salted water. In regard to this, the decision was made for a dry heat loss manikin. However, the size of an average-sized person was chosen to obtain the best size possible.

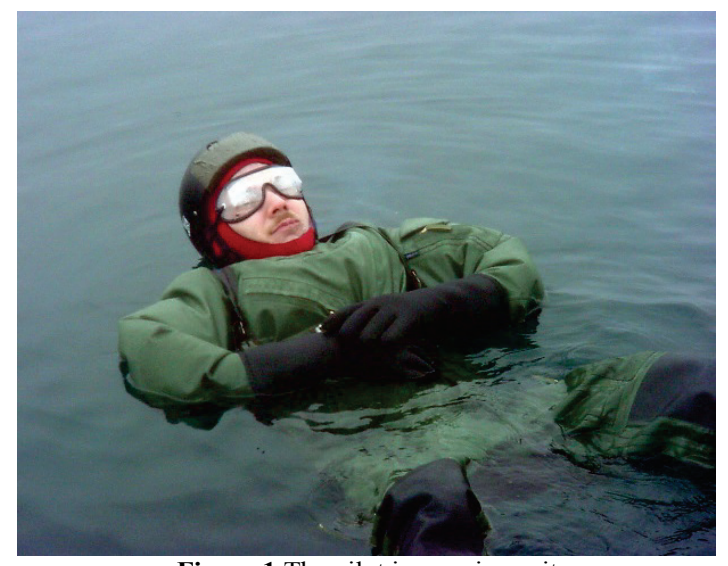

Figure 1 The pilot immersion suit

\subsection{Immersion manikin construction requirements 2.2.1 Heating}

Under normal conditions, a human produces around $100 \mathrm{~W}$ of heat energy but under extreme working conditions the human body can produce more than 500 $\mathrm{W}$, so to acquire relevant results or to shorten the time of preheating before the measurement of some additional power reserve is needed. According to the desired simulation of a human body, the required heating power was set at $1000 \mathrm{~W}$.

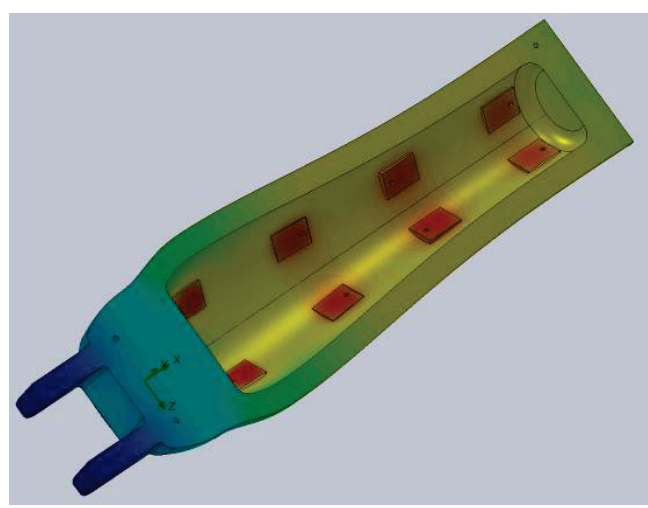

Figure 2 Simulation of heat distribution before the final placements of heating elements for optimising the heat distribution

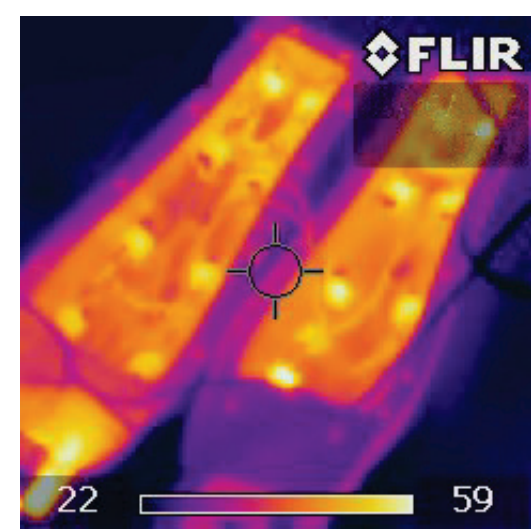

Figure 2 Confirmation of the created simulations using an IR camera 
For heating we chose electrical heaters that worked on the resistance principle and the number of them was optimised in order to obtain the best possible heat distribution (Figs. 2 and 3). The choice of small resistance in the TO220 housing was made in order to obtain a compact design with an easy to fix shape.

\subsubsection{Material for outer shell}

The manikin's shell was made of aluminium AlMg5Si01 which is a cost-efficient replacement for the silver that was also envisaged but was then replaced because of the need for thicker walls in order to ensure the self-carrying of the manikin's body. The more important requirements were thermal conductivity and resistance to salted water.

The material had to comply with the mechanical loadings that would occur during usage and testing. The total weight of the immersion manikin is $75 \mathrm{~kg}$. The mass of the material is the principal loading during the use. During the preparation for testing, the manikin was suspended to a vertical position because of donning and removing the garments, whilst during the immersion tests the manikin was placed into water in a horizontal position. The outside surfaces were coated with galvanic chromium plating and then varnished in white so as to create a smooth surface.

\subsubsection{Construction design}

The manikin's body was constructed according to the measurements of an average human body using Catia V5 CAD software. Catia V5 is widely used in the automotive and aircraft industries and as such allows the user simple and accurate design possibilities for constructing complex shapes. The construction should disallow improper usage of the product or damages to the product and users during the operation [9]. In order to enable production, the properties had to be suitable for small series productions, cost, material and surface qualities being taken into consideration [10].

2 (in order to obtain satisfactory results of heat distribution and accurate measurements.) 1 (The body was divided into 19 segments) So many segments were chosen because the measurements with the developed heat manikin (output data) would be connected with the numerical model for simulation of the human thermoregulatory responses. Each segment had its own heaters and sensor/control unit. Consecutively, each segment would provide its own thermal insulation data. Each segmental insulation data would present input data for thermoregulatory model. The construction design consisted of several steps:

- designing of the outer segment part according to human anatomy and average size,

- designing of the fixation points together with the movement mechanism; movements in neck, shoulder, elbow and hip required,

- designing of shell to gain suitable thickness; dimension of thickness should be as small as possible but it still needs to ensure stiffness of the segment and equal distribution of the material,
- designing of contact surface for heaters; big enough to fit the chosen heater design, equally distributed and at a tangent to the outer surface to ensure best possible heat distribution over the whole manikin body,

- scaling of the part according to the reduction of the cast part (in our case for aluminium casting 1,4\% scale of the model needed),

- measuring the weights and surface areas for each of the 19 bodily segments to obtain key data for heat loss calculations.

A special construction challenge was posed fitting the cable glands together with joints, where lack of space caused problems. Several different possibilities were tested and, at the end, the optimal option was chosen regarding heat distribution and movement space (Fig. 4). In order to verify the data calculated in the CAD program (area of a specific segment), a 3D scanning [11] of all segments was done after the manikin was fully assembled.

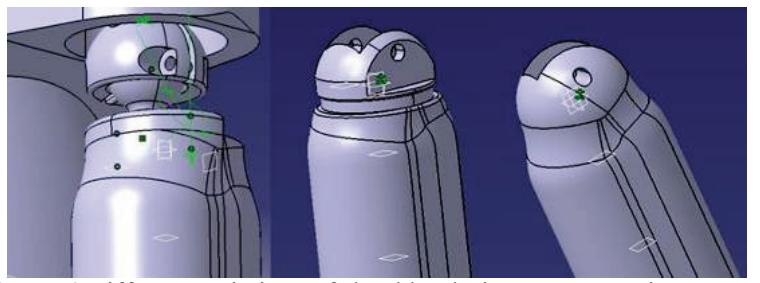

Figure 4 Different variations of shoulder design. Important issues were the reduction of heat loss caused by free space inside the joint area and the space for cable glands for connecting segments electrically

Before the parts were manufactured, the basic FEA analysis was made of the key points (areas where high loads were expected such as joints between segments). However, redesign was performed if necessary (Fig. 5). Problems occurred with those parts that during the testing were holding the manikin (head area) and were also exposed to greater temperature oscillation (neck and carrying hook).

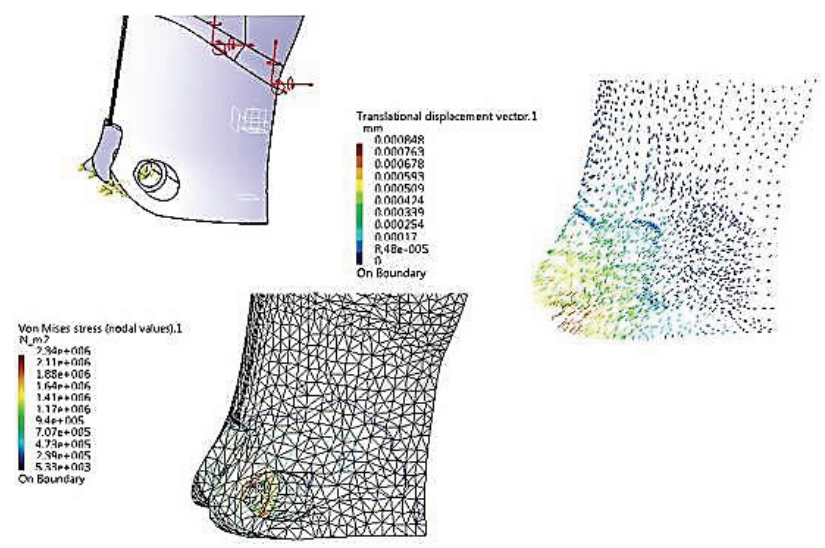

Figure 5 FEA analysis of a joint in the neck area

The last steps were the preparations of 2D sketches for dimension analysis and final machining of cast parts. Moreover, some negative shapes of complex parts were designed and manufactured in order to make the clamping of the work-piece possible. 


\section{Experiment}

\subsection{Manufacture using CAD/CAM tools}

The next step was the productions of individual segments. Direct production from the CAD/CAM tool Catia V5 could be possible but due to the stabilities of well-known production steps, conversion from Catia V5 in the shape of a neutral STEP data file was used for the UGS NX 7 program package. The production steps included:

- import and inspection of the STEP file,

- CAM programming,

- simulation of machining to obtain optimal results,

- machining of the part master model,

- casting of aluminium parts into a sand model,

- final machining of cast parts,

- assembly and water tightness tests.

The use of $\mathrm{CAD} / \mathrm{CAM}$ technology saved the time necessary for the elaboration of technological documentation, whereas considerable time saving could be observed during the productions of individual components. Current machine tools enable almost the entire productions of certain components by one clamping onto the same machine. NC programs are elaborated for such work pieces on the basis of 3D models and thus the human factor, which is more frequently the cause of faults, is largely excluded $[12,15]$.
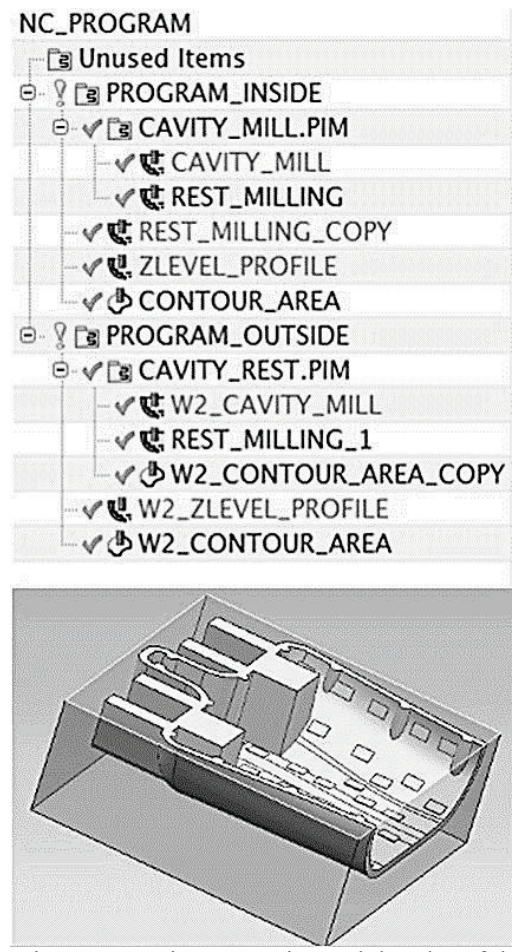

Figure 6 Various processing strategies and the plot of the raw work piece and the model of the lower torso part

Fewer mistakes also appear when designing models, as the $\mathrm{CAD} / \mathrm{CAM}$ technology enables verification of several variants of the same product. In addition, it includes the possibility of checking various interferences and determining other mistakes, as each model and each individual component can be seen from all angles like having a real physical object in front of you. After producing the first models, various programs for computational analysis need to be included in planning. Fewer mistakes occur, in particular where the volume model represents the basis for all $2 \mathrm{D}$ drawings and $\mathrm{NC}$ processing, and is saved only once and in only one place within the database $[16,17]$.

The first stage of production of single parts of the thermal manikin included the conversion of the STEP file into the PRT file which was suitable for the UGS NX 7 program package. The successful conversion of the CAD model of the product was followed by the identifications of adequate processing strategies and appropriate clamping of individual parts of the thermal manikin. Appropriate processing strategies were determined on the basis of previous experience using the UGS NX 7 program package [18, 19]. Fig. 6 shows various processing strategies for the lower part of the thermal manikin's torso.

For each individual segment of the thermal manikin, it was necessary to first begin programming and later manufacturing that side of the surface which would remain flat after the treatment. Processing strategies used on the outsides and insides of parts of the thermal manikin were similar, for example cavity milling, contour milling, $\mathrm{Z}$ level milling. For each processing strategy, it was necessary to set appropriate machining parameters based on simulations and experience. Machining parameters which varied according to various types of processing strategies were the following: tool (e.g. end mill tool, ball mill tool), processing method (rough and finish milling), depth of cutting, strategies of working and non-working strokes as well as spindle speed and feed rates (within these two parameters, finishing parameters such as depth of cut and step-over were adjusted). Fig. 7 shows the first stage of production of the internal upper part of the thermal manikin's torso using the end mill tool of $\varnothing 20$ $\mathrm{mm}$. This tool diameter was recognised as optimal regarding the productivity and reachability of corners.

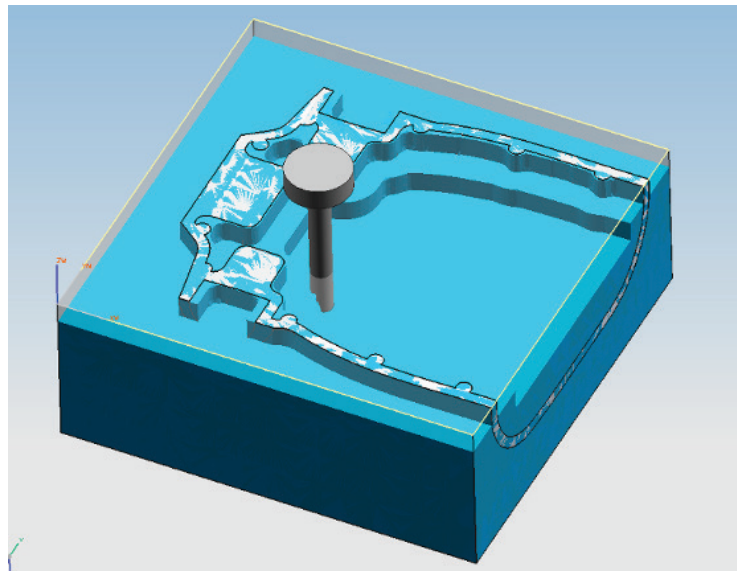

Figure 7 The figure shows a simulation of production of the uppe segment of the thermal manikin's torso

When planning the machining, adequate paths of the tool had to be taken into account so that the tool did not collide with the product or the clamping device. Fig. 8 shows the performance of the tool during the operation of cavity milling. In simulation of the manufacturing, a lot of attention was paid to the movement of the tool between individual levels or planes of treatment, and special care 
had to be taken for individual shifts of the tool over the entire single part of the thermal manikin i.e. work piece.

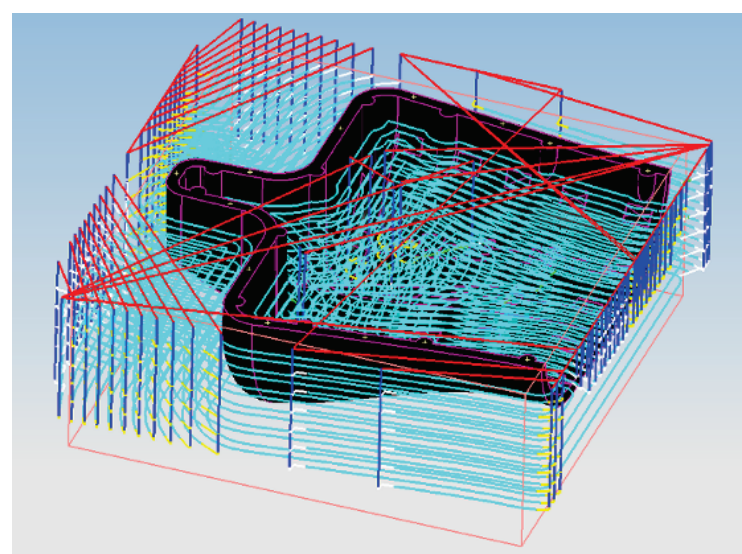

Figure 8 Plot of the path for the lower segment of the thermal manikin's torso

The productions of individual segments of the thermal manikin were carried out using the $\mathrm{CNC}$ machine centre Heller BEA 1. The material for the production of individual segments of the thermal manikin with the CNC machine centre Heller BEA 1 was SikaBlock ${ }^{\circledR}$ M700 (Polyurethane Model Board, dimensions $500 \mathrm{~mm} \times 497$ $\mathrm{mm} \times 100 \mathrm{~mm})$. Individual blocks had to be cut-up according to the sizes of the preliminary determined raw work pieces required for individual parts of the thermal manikin.

Individual segments of the thermal manikin's body were divided into partial pieces due to the capabilities of the CNC machine (Fig. 9). As an example, the thermal was divided into four non-symmetrical parts not only due to limited working space of the machine, amounting for the $\mathrm{X}$-axis to $630 \mathrm{~mm}$, for the $\mathrm{Y}$-axis to $500 \mathrm{~mm}$ and for the $\mathrm{Z}$-axis to $630 \mathrm{~mm}$ but also due to the technological requirements of aluminium casting.

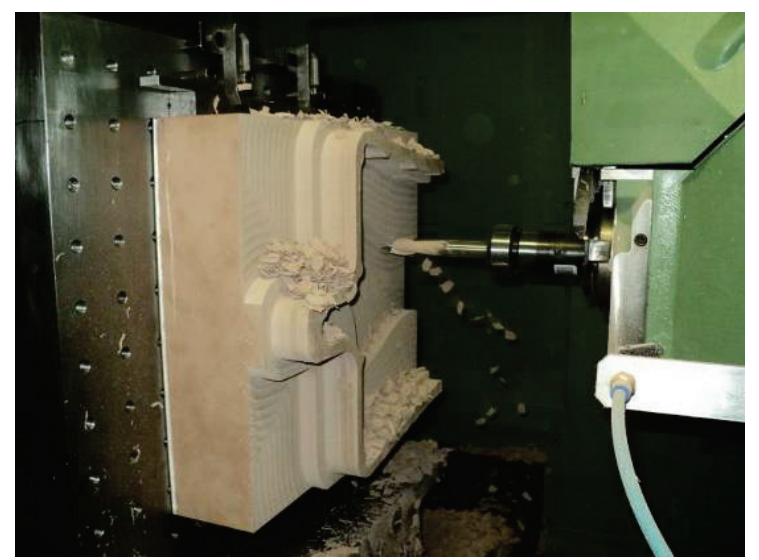

Figure 9 The process of manufacturing a part of the thermal manikin's torso with the $\mathrm{CNC}$ machine centre $\mathrm{BEA} 1$

Individually the manufactured parts of the thermal manikin from SikaBlock ${ }^{\circledR}$ were glued using a two component adhesive and then delivered to a small foundry where the casts of these individual parts were made from the aluminium alloy.

After delivering the cast parts, they were machined using conventional milling machine (Fig. 10). Special attention was given to the joints and contact surfaces, which have to ensure water tightness.

The surface roughness was affected by many controlled and uncontrolled process parameters that were difficult to achieve and continuously monitor [20].

Afterwards all body parts of the thermal manikin were assembled into a whole. When processing individual parts, special attention had to be paid to precisely made contacts between the individual divided parts of the thermal manikin's body due to providing appropriate water tightness.

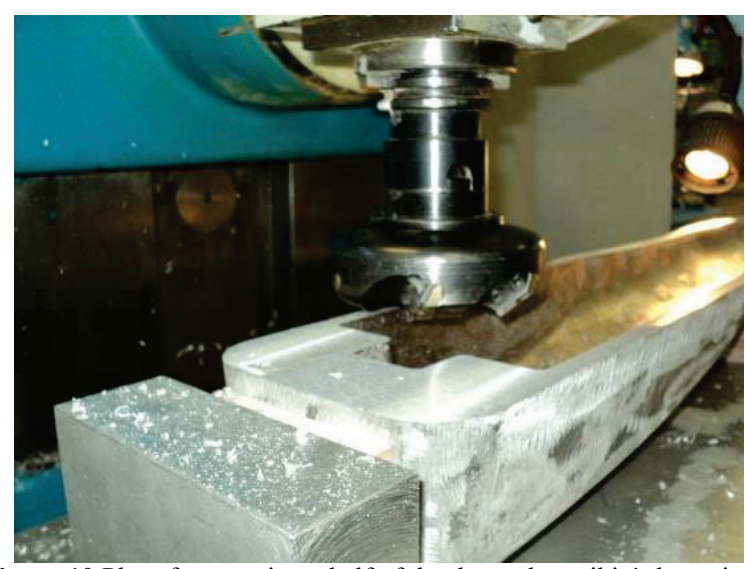

Figure 10 Plot of processing a half of the thermal manikin's leg using a three-axis conventional milling machine

Processing of the thermal manikin's torso was carried out with the use of conventional machines and was relatively demanding due to the size of the torso itself (Fig. 11). In order to perform the clamping successfully, it was necessary to use various standard devices for clamping, whereas some accessories for certain parts of the thermal manikin i.e. moulds had to be produced separately for each part.

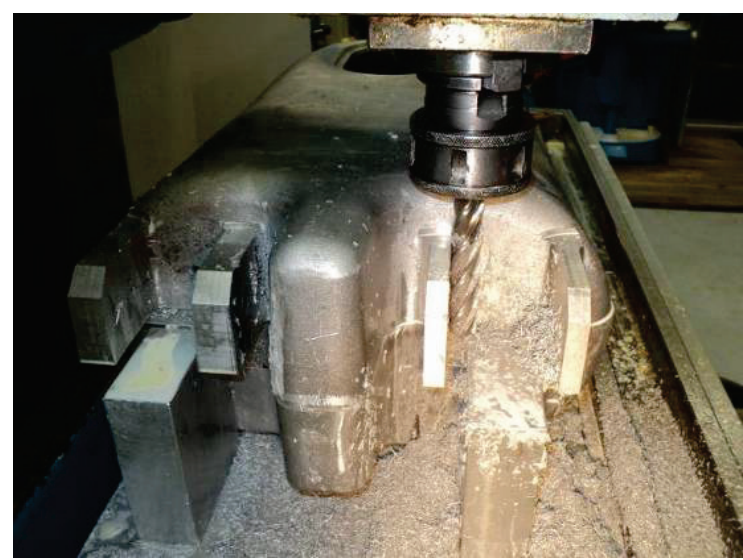

Figure 11 Milling of the backside part of the thermal manikin's torso

The assembly of the particular segments of the thermal manikin was performed without major complications or inconveniences. Thermal manikin was hung on the console while donning the test garments (Fig. 12).

The process of producing the thermal manikin from the CAD model of the product, CAM programming, CNC production, aluminium casting as well as final treatment and assembly required a lot of planning, calculating and coordinating between individual participants. 


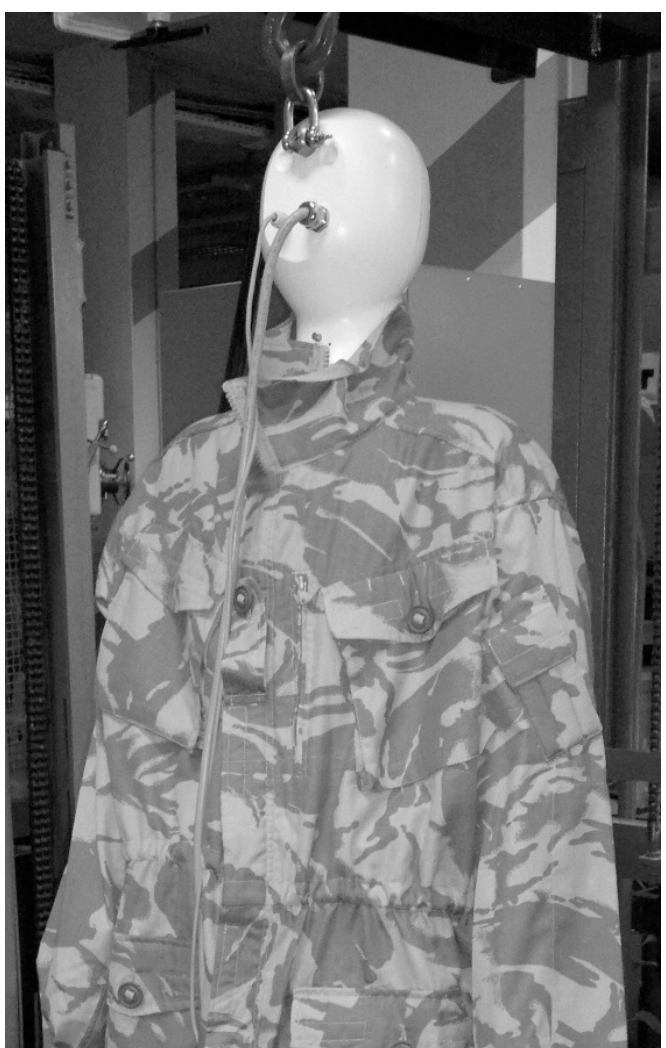

Figure 12 Fully assembled thermal manikin

\subsection{Embedding with the electronics}

Electronic measurement components were developed especially for this type of the manikin. 2 (because of the demand for water tightness and the real life use in salted water.) 1(A more careful approach to the problem was adopted)

\subsubsection{Power supply}

The complete power electronics (with FET transistors) is divided into two parts, each supplying its body half. Two separated power supply units were chosen each capable of $600 \mathrm{~W}$ at $48 \mathrm{VDC}$. A built in electronic was heated with the same energy as it consumes and that energy heated-up the manikin's body, so in order to obtain accurate results the heat of the electronic components was added to the heat of the segment where the electronic was built in.

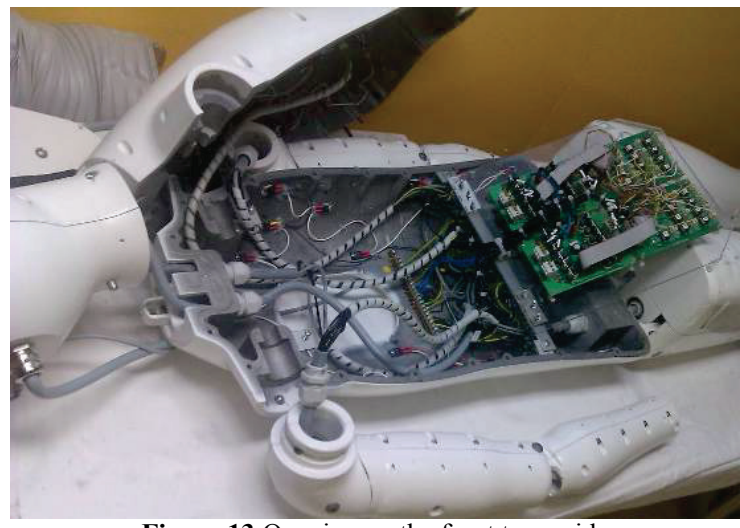

Figure 13 Opening on the front torso side
In order to establish control, microcontrollers were used where each of them was handling the data of an individual segment and adapting the power to the heater through PWM control and PID regulation (Fig. 13). There are two possible regulation modes of heaters - constant skin temperature or constant heat flux.

The front part of the manikin torso has an opening that serves for small repairs or settings. Such an opening eliminates the need for disassembling the overall body manikin.

\subsubsection{Data transfer}

The requirement for water tightness also demanded a solution for a data handling system at a larger distanceaway from the manikin itself, so a robust system of data transmission had to be chosen as well. In order to establish the data transfer from the manikin to the control unit, a wireless connection was taken into consideration but was ultimately, due to reliability, replaced with a classical robust cable connection (RS 485 protocol). All data were sent to the PC that was connected to the control unit with a USB cable.

\subsubsection{Temperature sensors}

Good reliable and accurate sensors were chosen for temperature measurements. High-Precision 1 - Wire Digital Thermometers DS18S20 [21] from Maxim that allow a $\pm 0,5{ }^{\circ} \mathrm{C}$ accuracy within the range from $-10{ }^{\circ} \mathrm{C}$ to $+85^{\circ} \mathrm{C}$ were positioned to the body surface.

\subsection{User interface}

We developed a suitable user interface for capturing the data.The user interface is designed to ensure a good overview of all crucial data, temperature and power. It enables simple and controlled testing according to ISO 15831 (2004) [22] standard. Each of the nineteen segments' communicates with the control unit and the data on the user interface is shown in real time (Fig. 14). So if a failure occurs, the operator can see which segment is not functioning.

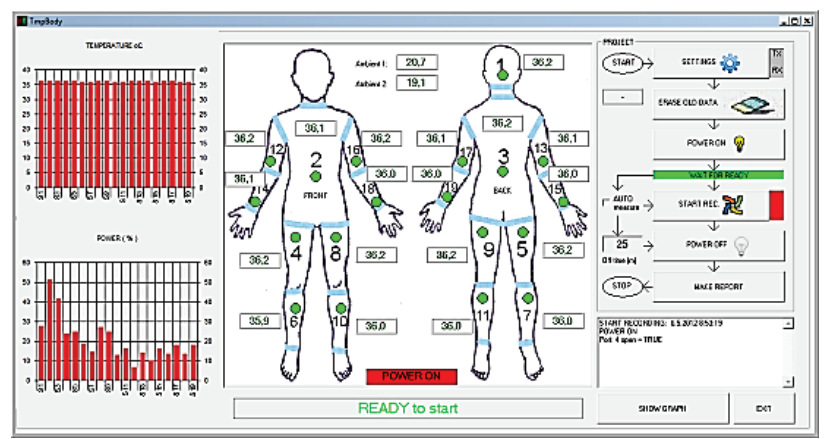

Figure 14 Control panel of the user interface

The control panel presents all nineteen segments with measured temperatures. On the left side is also a graphic presentation of reached temperature and current power (in $\%$ of maximum possible load) conducted to a certain segment. The right side allows measurements according to ISO 15831 (2004) standard with a documented report. 
The most important result that we want to obtain during the testing using an immersion manikin is thermal insulation that increases with each added textile layer inside the clothing system (Fig. 15). In order to convert the measurements into useful data the thermal resistance $\left(R_{t i}\right)$ and total clothing thermal insulation value $\left(I_{i}\right)$ can be calculated automatically for each of nineteen segments or all segments together.

Thermal resistance of a particular manikin segment in clo is calculated as follows:

$R_{t i}=\frac{T_{s, i}-T_{\mathrm{amb}}}{0,155 Q_{i}}$

where:

$T_{s, i}-$ surface temperature of segment $i(\mathrm{~K})$

$T_{\mathrm{amb}}-$ ambient temperature $(\mathrm{K})$

$Q_{i}$ - rate of heat transfer $\left(\mathrm{Wm}^{-2}\right)$

0,155 - factor for conversion from $\left(\mathrm{m}^{2} \mathrm{KW}^{-1}\right)$ to (clo).

The total clothing thermal insulation of a manikin segment in clo is calculated as follows:

$I_{i}=\frac{A_{i}\left(T_{s, i}-T_{\mathrm{amb}}\right)}{0,155 Q_{i}}$

where:

$A_{i}-$ surface of the particular manikin segment $\left(\mathrm{m}^{2}\right)$.

By using the user interface, the measured results of each of nineteen segments can be displayed in real time (Fig. 16). Any impact from the environment can be observed during the heating-up of the surface temperature as well during the measuring. All measured data can be saved or printed out.

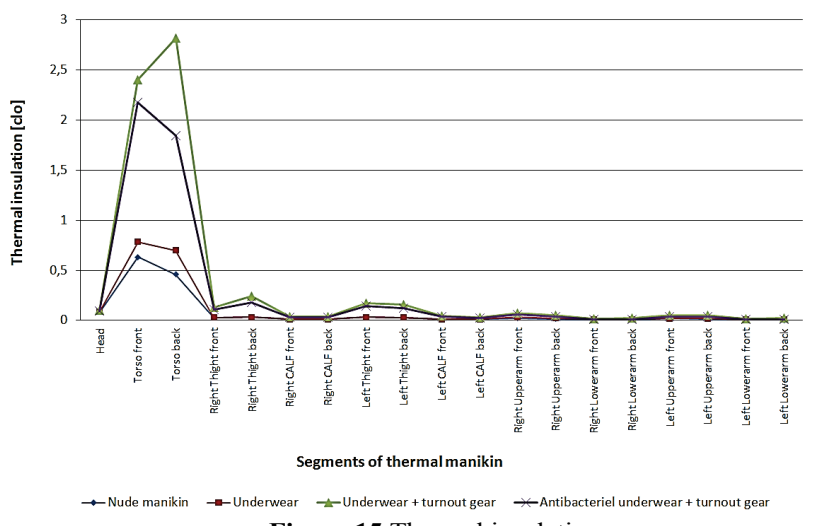

Figure 15 Thermal insulation

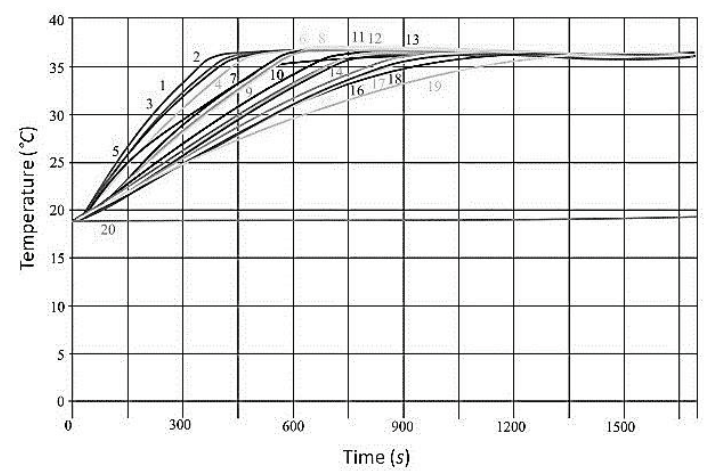

Figure 16 Graph display of real time measurements.
The heating is presented of all nineteen segments from room temperature to a set temperature of $36{ }^{\circ} \mathrm{C}$. Tags from 1 to 19 present manikin segments and tag 20 presents the temperature of environment. Due to different masses and applied power, the segments were not heated at the same rates during the preheating phase. Measurement started under stable condition.

\section{Conclusions}

Thermal manikins designed for simulations of the human body under normal and extreme conditions have already been presented in certain areas [23 $\div 28]$. Below, because of the presented measurements of thermal resistance regarding particular segments of the human body and total clothing thermal insulation according to the prescribed standards, the manikin can also be used for other specific evaluations of garment ensembles and/or human responses under extreme environmental conditions. Using the thermal manikin special evaluations can be made, such as: measuring the amount of water in the trachea during an epileptic attack in the water, measuring the time of suppression by water mist, establishing the time until the temperature shock when falling into cold water, optimisation of the climate systems in vehicles, cars and in public transportation, optimisation of optimal conditions in buildings (hospitals, schools, homes for elderly people); a special head model for protective helmet testing, a special feet model for footwear testing, a special hand model for gloves' testing, etc.

This paper presented the production of a thermal immersion manikin made from solid blocks. In the initial phase of the study and based on the expertise of the research group, a suitable material was selected for processing into the $3 \mathrm{D}$ shape of the human body. The selection was based on a study of the thermal, mechanical and chemical properties of the material. Next the appropriate manufacture processes were selected. The biggest challenge has been to construct the moving parts of the manikin, in particular on the shoulder portion, as shown in Fig. 4. The requirements must be fulfilled of tightness, moving of arms in the shoulder section, limitation of space, wiring for heating and data transmission.

Irrespective of the difficulty of the challenge, the thermal immersion manikin was developed and manufactured for use in the development departments of different clothing systems, protective as well of recreational, Fig. 12. We have successfully combined the research fields of protection and rescuing, textile and clothing engineering and of production technologies. In the next steps of the presented study, the manufactured thermal immersion manikin will be used for the evaluation of different clothing ensembles. Such an approach will also allow further evaluation of the immersion manikin itself as well as of the user interface.

\section{Acknowledgements}

Project "Production of a New Generation of the Thermal Manikin for Evaluation of Personal Protective Equipment and Safety of Health in Extreme Working and 
Living Environmental Conditions (X-TERMOMAN)" (L2-4107) is part-financed by the Slovene Research Agency.

The presented manikin was the first manikin made at the Faculty of Mechanical Engineering in Maribor in collaboration with the Josef Stefan Institute and industrial partner Biomed d.o.o.

The latter is the owner of the first thermal manikin made in Slovenia (Fig. 1). To obtain the best size possible, the size of an average sized person was chosen. In Slovenia, the bases for that were the measurements by the army where all the volunteers were measured and the average sizes of human parts were obtained. Data was compared to anthropometric data from other countries and were adapted (just small changes in dimensions) for the first end used as a test platform for a diving suit in the army.

\section{References}

[1] Holmér, I. Thermal manikin history and applications. // European Journal of Applied Physiology. 92, 6(2004), pp. 614-618. DOI: 10.1007/s00421-004-1135-0

[2] Wu, T.; Tian, R.; Duffy, V. G. Performing ergonomics analyses through virtual interactive design: Validity and reliability assessment. // Human factors and ergonomics in manufacturing \& service industries. 22, 3(2012), pp. 256268. DOI: $10.1002 / \mathrm{hfm} .20267$

[3] Oliveira, A.; Virgilio, M.; Gaspar, A. R.; Quintela, D. A. Dynamic clothing insulation. Measurements with a thermal manikin operating under the thermal comfort regulation mode. // Applied Ergonomics. 42, 6(2011), pp. 890-899. DOI: 10.1016/j.apergo.2011.02.005

[4] Pavlinic, D. Z.; Wissler, E. H.; Mekjavic, I. B. Using a mathematical model of human temperature regulation to evaluate the impact of protective clothing on wearer thermal balance. // Textile research journal. 81, 20(2011), pp. 2149-2159. DOI: 10.1177/0040517511414971

[5] DuPont ${ }^{\mathrm{TM} T h e r m o-m a n}{ }^{\circledR}$. URL: http://www2.dupont.com/ personal-protection/en-us/dpt/thermo-man.html/ (10.6.2012)

[6] Thermal measurement systems. URL:http://thermal.mtnwusa.com/ (29.10.2012)

[7] Walter ${ }^{\mathrm{TM}}$. Sweating Manikin Laboratory. URL:http://www.itc.polyu.edu.hk/en/about/facilities walter sweating_manikin_lab.html/ (29.10.2012)

[8] Thermal manikins for science and industrial use. URL: http://pt-teknik.dk/ (29.10.2012)

[9] Madani, R.; Moroz, A.; Baines, E. Design and manufacturing of children's remote control for child viewing. // Advances in Production Engineering \& Management. 8, 2(3013), pp. 116-125.

[10] Valentan, B.; Brajlih, T.; Drstvenšek, I.; Balič, J. Development of a part-complexity evaluation model for application in additive fabrication technologies. // Strojniski Vestnik. 57, 10(2011), pp. 709-718. DOI: 10.5545/sv-jme.2010.057

[11] Brajlih, T.; Tasič, T.; Drstvenšek, I.; Valentan, B.; Hadžistević, M.; Pogačar, V.; Balič, J.; Ačko, B. Possibilities of using three-dimensional optical scanning in complex geometrical inspection. // Strojniski vestnik. 57, 11(2011), pp. 826-833. DOI: 10.5545/sv-jme.2010.152

[12] Balic, J. Intelligent $\mathrm{CAD} / \mathrm{CAM}$ System for $\mathrm{CNC}$ Programming - An Overview. // Advances in Production Engineering \& Management. 1, 1(2006), pp. 13-22.

[13] Klancnik, S.; Senveter, J. Computer-Based Workpiece Detection on CNC Milling Machine Tools Using Optical
Camera and Neural Networks. // Advances in Production Engineering \& Management. 5, 1(2010), pp. 59-68.

[14] Srikant, R. R.; Siva, S. M.; Krishna, V. P. Experimental selection of special geometry cutting tool for minimal tool wear. // Advances in Production Engineering \& Management. 5, 1(2010), pp. 13-24.

[15] Ficko, M.; Balic, J.; Pahole, I.; Senveter, J.; Brezovnik, S.; Klancnik, S. Expectations of automatic programming of CNC machine tools. // Advances in Production Engineering \& Management. 5, 3(2010), pp.193-199.

[16] Senveter, J.; Klancnik, S.; Balic, J.; Cus, F. Prediction of surface roughness using a feed-forward neural network. // Management and Production Engineering Review. 1, 2(2010), pp. 47-55.

[17] Stephenson, D. A.; Agapiou, J. S. Metal Cutting Theory and Practice, Second Edition. CRC Taylor \& Francis Group, Boca, Raton, London, New York, 2006.

[18] Klancnik, S.; Balic, J.; Cus, F. Intelligent prediction of milling strategy using neural networks. // Control Cybernetics. 39, 1(2010), pp. 9-22.

[19] Siemens Product Lifecycle Management Software Inc. // NX CAM Customization Student Guide MT11075 - NX 7. Camberley, Surrey, United Kingdom, 2009.

[20] Saric, T.; Simunovic, G.; Simunovic, K. Use of Neural Networks in Prediction and Simulation of Steel Surface Roughness. // International Journal of Simulation Modelling. 12, 4(2013), pp. 225-236. DOI: 10.2507/IJSIMM12(4)2.241

[21] DS18S20 - High-Precision 1 Wire Digital Thermometer: datasheet. URL: http://datasheets.maxim-ic.com/en/ ds/DS18S20/ (15. 5. 2012)

[22] ISO 15831 (2004) Clothing-physiological effects. // Measurement of thermal insulation by means of a thermal manikin. / International Organization for Standardization, Geneva, Switzerland, 2004.

[23] Morabito, M.; Zavec Pavlinic, D.; Crisci, A.; Capecchi, V.; Orlandini, S.; Mekjavic, I. B. Determining optimal clothing ensembles based on weather forecasts, with particular reference to outdoor winter military activities. // International journal of biometeorol. 55, 4(2011), pp. 481490. DOI: $10.1007 / \mathrm{s} 00484-010-0357-6$

[24] Qian, X.; Fan J. Prediction of Clothing Thermal Insulation and Moisture Vapour Resistance of the Clothed Body Walking in Wind. // The Annals of Occupational Hygiene. 50, 8(2006), pp. 833-842. DOI: 10.1093/annhyg/mel050

[25] Chen, Y. S.; Fan, J.; Zhang, W. Clothing thermal insulation during sweating. // Textile Research Journal. 73(2003), pp. 152-157. DOI: $10.1177 / 004051750307300210$

[26] Holmér, I. Required clothing insulation (IREQ) as an analytical index of cold stress. // ASHRAE Trans 90. (1984), pp. 1116-1128.

[27] Umbach, K. H. Physiological tests and evaluation models for the optimisation of the performance of protective clothing. // Environmental Ergonomics. Sustaining Human Performance in Harsh Environments. / Eds.: Mekjavic, I. B.; Banister, E. W. and Morrison, J. B. Philadelphia : Taylor \& Francis, 1987, pp. 139-161.

[28] Zavec, P. D.; Mekjavic, I. B. Needs of the environment are shaping the combat clothing systems. // Slovenian Armed Forces Magazine.10, (2009), pp. 29-31. 


\section{Authors' addresses}

Assoc. Prof. Ivo Pahole, D. Sc.

University of Maribor, Faculty of Mechanical Engineering

Smetanova ul. 17, SI-2000 Maribor, Slovenia

E-mail: ivan.pahole@um.si

Bogdan Valentan, D. Sc.

University of Maribor, Faculty of Mechanical Engineering

SI-2000 Maribor, Slovenia

E-mail: valentan@gmail.com

Assoc. Prof. Daniela Zavec Pavlinić, D. Sc.

Titera d.o.o.

Obrtna ulica 40, SI-9000 Murska Sobota, Slovenia

E-mail: dzpavlinic@gmail.com

Assist. Prof. Mirko Ficko, D. Sc.

University of Maribor, Faculty of Mechanical Engineering

Smetanova ul. 17, SI-2000 Maribor, Slovenia

E-mail: mirko.ficko@um.si

Prof. Jože Balič, D. Sc.

University of Maribor, Faculty of Mechanical Engineering

Smetanova ul. 17, SI-2000 Maribor, Slovenia

E-mail: joze.balic@um.si 